\title{
Biological and molecular properties of yellow venom of the Amazonian coral snake Micrurus surinamensis
}

\author{
Fabiana da Rocha Oliveira[1], Maria das Dores Nogueira Noronha ${ }^{[2]}$ \\ and Jorge Luis Lopez Lozano ${ }^{[2]}$
}

[1]. Laboratório de Ecologia e Biotecnologia de Microrganismos da Amazônia, Instituto Nacional de Pesquisas da Amazônia, Manaus, AM, Brasil. [2]. Centro de Ofidismo da Amazônia, Fundação de Medicina Tropical Doutor Heitor Vieira Dourado, Manaus, AM, Brasil.

\begin{abstract}
Introduction: The coral snake Micrurus surinamensis, which is widely distributed throughout Amazonia, has a neurotoxic venom. It is important to characterize the biological and molecular properties of this venom in order to develop effective antitoxins. Methods: Toxins from the venom of $M$. surinamensis were analyzed by two-dimensional polyacrylamide gel electrophoresis and their neurotoxic effects in vivo were evaluated. Results and Conclusions: Most proteins in the venom had masses $<14 \mathrm{kDa}$, low phospholipase A2 activity, and no proteolytic activity. The toxins inhibited the coagulation cascade. The venom had neurotoxic effects in mice, with a median lethal dose upon intravenous administration of $700 \mu \mathrm{g} / \mathrm{kg}$. Immunogenic studies revealed abundant cross-reactivity of antielapidic serum with $14 \mathrm{kDa}$ toxins and limited cross-reactivity with toxins $<10 \mathrm{kDa}$. These results indicate that antielapidic serum against $M$. surinamensis venom has weak potency $(0.35 \mathrm{mg} / \mathrm{ml})$ in mice.
\end{abstract}

Keywords: Micrurus surinamensis. Neurotoxins. Phospholipase A2. Biological activities.

\section{INTRODUCTION}

Approximately 800 species of reptiles have been identified throughout the Brazilian territory; more than $50 \%$ of these are snakes including coral snakes, which are members of the Elapidae family ${ }^{1}$ comprising approximately 40 genera $^{2}$. Only the genera Micruroides Schmidt, 1928 (North America); Leptomicrurus Schmidt, 1937 (South America); and Micrurus Wagler, 1824 are found in the Americas ${ }^{3,4}$ in fossorial or aquatic habitats. Coral snakes are small animals, ranging from $20 \mathrm{~cm}$ to just over $1 \mathrm{~m}$ in length, and have fixed venom inoculators of the proteroglyphous type. In general, they do not attack; poisoning by these snakes only occurs when they are handled or trampled. Hence, envenomation is rare although the effects can range from mild to severe, since the venom is highly neurotoxic; symptoms include myasthenia (e.g., weakness and ptosis) that can evolve to paralysis and respiratory failure $e^{6-8}$.

The venom components responsible for its toxicity include phospholipase (PL) A2 and neurotoxins. Both of these have low molecular masses $(<15 \mathrm{kDa})$ and are neuro- and myotoxic ${ }^{9-11}$. PLA2 may also have coagulant/anticoagulant effects $^{12-16}$. Neurotoxins are categorized as $\beta$-neurotoxins (presynaptic),

Corresponding author: Dra. Fabiana da Rocha Oliveira.

e-mail: fabirochaoliveira@gmail.com

Received 25 October 2016

Accepted 11 April 2017 $\alpha$-neurotoxins (postsynaptic), cardiotoxins, and weak neurotoxins depending on their mode of action. $\beta$-neurotoxins block acetylcholine $(\mathrm{ACh})$ release after neurotransmission and thereby prevent action potentials, whereas $\alpha$-neurotoxins compete with $\mathrm{ACh}$ at nicotinic cholinergic receptors of motor endplates. Both act at the neuromuscular junction where they block nerve impulses and cause total paralysis of skeletal muscle ${ }^{17-21}$. Cardiotoxins induce muscle cell depolarization and contraction and cell membrane disruption, damaging erythrocytes and epithelial cells ${ }^{22}$; weak neurotoxins have effects similar to those of $\alpha$-neurotoxins but are less toxic ${ }^{23}$.

Six species of coral snake have been identified as medically important in the State of Amazonas in Brazil: Micrurus averyi, Micrurus filiformes, Micrurus hemprichii, Micrurus lemniscatus, Micrurus spixii, and Micrurus surinamensis. These species are associated with low mortality rates in humans ${ }^{24,25}$. Given the diversity and abundance of coral snakes across the northern region of Brazil, biochemical studies of their venom have attracted wide interest.

Micrurus surinamensis has red cephalic scales with black borders and a red/black/yellow ring pattern, with the black rings arranged in perfect triads (Figure 1). Micrurus surinamensis lives in swampy areas (igapós) and streams in the primary forest area and feeds primarily on fish, but has a broad geographic distribution that includes southeastern Venezuela; Guianas; and the Amazonian regions of Colombia, Ecuador, Peru, Bolivia, and Brazil (Amapá, Amazonas, Pará, Maranhão, and Mato Grosso) $)^{4,26,27}$. The venom of $M$. surinamensis is distinct from that 


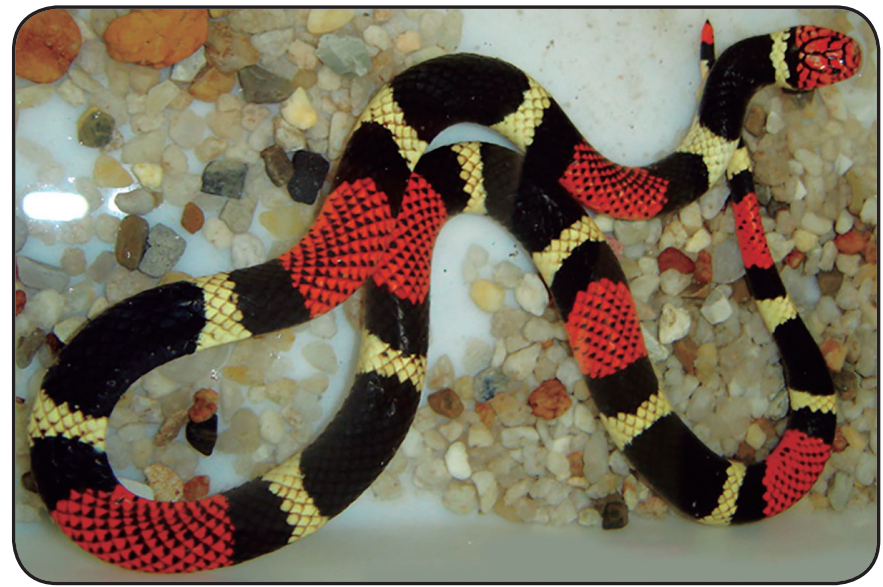

FIGURE 1 - Micrurus surinamensis (Cuvier, 1817). Photo: Prof. Paulo F. Bürnheim, 1998.

of other Micrurus species in terms of enzymatic composition ${ }^{28,29}$, as evidenced from the protein expression profile. In the present study, we investigated the molecular composition and biological and neurotoxic activities of the venom of M. surinamensis, as well as the capacity of antielapidic serum to neutralize the neurotoxicity and lethal effects of this venom.

\section{METHODS}

\section{Animals and venom}

Mice (BALB/cJ) weighing 18-22g were provided by Professor Paulo Friederich Bührnheim of the Experimental Animal Lab of Molecular Toxicology Laboratory Snakebite Center, Tropical Medicine Doctor Heitor Vieira Dourado Foundation, Amazonas, Brazil. The animals were maintained in plastic cages under a controlled temperature ranging from $22^{\circ} \mathrm{C}$ to $25^{\circ} \mathrm{C}$ with free access to water and food. The experiments were carried out according to local guidelines for the care and use of laboratory animals.

We extracted venom from snakes by pressing the head against a small glass vial covered with a Parafilm membrane, with microcapillary tubes under the teeth. Lyophilized crude yellow venom from $M$. surinamensis (pooled from adult animals) provided by the Molecular Toxicology Laboratory of Venoms bank and developed by the Snakebite Center was stored $-20^{\circ} \mathrm{C}$.

\section{Tris-tricine polyacrylamide gel electrophoresis}

Tris-tricine polyacrylamide gel electrophoresis (PAGE) was carried out according to a previously described method ${ }^{30}$. The stacking gel consisted of $1.1 \mathrm{ml}$ glycerol; $3.3 \mathrm{ml}$ gel buffer composed of $3 \mathrm{M}$ Tris- $\mathrm{HCl}$ and $0.3 \%$ sodium dodecyl sulfate (SDS) (pH 8.45); $3.3 \mathrm{ml}$ of $46.5 \%$ acrylamide $/ 3 \%$ bisacrylamide solution; $2.3 \mathrm{ml}$ ultrapure water; $0.7 \%$ ammonium persulfate [(APS); $100 \mathrm{mg} / \mathrm{ml}$; and $0.7 \% \mathrm{~N}, \mathrm{~N}, \mathrm{~N}^{\prime}, \mathrm{N}^{\prime}-$ tetramethylethylenediamine (TEMED) in a final volume of $10 \mathrm{ml}$. The separating gel consisted of $2.5 \mathrm{ml}$ gel buffer, $1.5 \mathrm{ml}$ $48 \%$ acrylamide $/ 1.5 \%$ bisacrylamide solution, $3.5 \mathrm{ml}$ ultrapure water, $0.7 \%$ APS, and $0.7 \%$ TEMED in a final volume of $7.5 \mathrm{ml}$.
Samples were dissolved in $0.05 \mathrm{M}$ Tris- $\mathrm{HCl}$ sample buffer (pH 6.8), and a protein load of $20 \mu \mathrm{g}$ was separated by PAGE. Samples were reduced by applying dithiothreitol at a final concentration of $0.1 \mathrm{M}$. Bothrops atrox venom toxin was used as molecular mass standards $(50,23$, and $14 \mathrm{kDa})$. Gels were stained with Coomassie Blue R-250 to reveal protein bands.

\section{Two-dimensional (2D) gel electrophoresis}

Nonlinearly immobilized $\mathrm{pH}$ gradient (IPG) Immobiline DryStrips (24cm in length with a pH gradient of 3.0-10.0 and $13 \mathrm{~cm}$ in length with a $\mathrm{pH}$ gradient of 4.0-7.0 or 7.0-11.0) (GE Healthcare, Little Chalfont, UK) were hydrated for $12 \mathrm{~h}$ with $500 \mu \mathrm{g}$ of $M$. surinamensis venom in sample buffer. Isoelectric focusing was carried out using an IPGphor III system (GE Healthcare). The IPG strips were separated according to mass by PAGE.

Discontinuous gels were obtained for the 24-cm strips with a $\mathrm{pH}$ gradient of 3.0-10.0. The $4 \%$ stacking gel and $15 \%$ separating gel were prepared from a $30 \%$ acrylamide solution and $0.8 \% \mathrm{~N}, \mathrm{~N}$ methylene-bisacrylamide dissolved in ultrapure water. The separating gel was prepared using $1.5 \mathrm{M}$ Tris- $\mathrm{HCl}$ buffer ( $\mathrm{pH} 8.8$ ) containing $0.1 \%$ SDS to solubilize the samples and $0.7 \%$ APS and $0.7 \%$ TEMED to polymerize the gel. The stacking gel was prepared after polymerization using $0.5 \mathrm{M}$ Tris$\mathrm{HCl}$ buffer (pH 6.8), 0.1\% SDS, 0.7\% APS, and 0.7\% TEMED.

Gradient gels (5\%-20\% polyacrylamide) were prepared using 13-cm IPG strips with $\mathrm{pH}$ gradients of 4.0-7.0 and 7.0-11.0. The resolving gel was prepared using acrylamide stock solution and $3.0 \mathrm{M}$ Tris-HCl buffer $(\mathrm{pH} 8.8)$, to which $400 \mu$ l of sucrose ( $1 \%$ by volume) were added. The spacer gel consisted of acrylamide stock solution and 3.0M Tris- $\mathrm{HCl}$ buffer $(\mathrm{pH}$ 8.8). The stacking gel was prepared from acrylamide stock solution and $0.5 \mathrm{M}$ Tris- $\mathrm{HCl}$ buffer $(\mathrm{pH} 6.8)$. B. atrox venom toxins $(10 \mu \mathrm{g})$ were used as molecular mass markers $(50,23$, and $14 \mathrm{kDa}$ ). All gels were scanned and analyzed using the Image Master 2D Platinum 6.0 system (GE Healthcare) according to the manufacturer's instructions.

\section{Intracranial injection of mice}

The neurotoxic effects of $M$. surinamensis venom on the mammalian central nervous system (CNS) were evaluated. Four groups of three mice were intracranial (i.c.) injected with $0.2,1$, 2 , or $4 \mu \mathrm{g}$ venom diluted in physiological saline $(0.15 \mathrm{M} \mathrm{NaCl})$. Samples were preincubated in a water bath at $37^{\circ} \mathrm{C}$ for $10 \mathrm{~min}$ prior to injection. Physiological saline was used as a control. A 1-ml insulin syringe equipped with a $0.3-\mathrm{mm}$ needle (UltraFine II; BD Biosciences, Franklin Lakes, NJ, USA) was used for injection. The needle size was modified to a length of $3 \mathrm{~mm}$ to accommodate the depth of insertion into the rat cranium. The animals were immobilized with their heads in a horizontal position, and the venom in a final volume of $20 \mu \mathrm{l}$ was injected into the dorsal region of the frontal lobe at the longitudinal fissure. After inoculation, the animals were observed for $48 \mathrm{~h}$ and neurological symptoms and mortality were documented.

\section{Calculation of $50 \%$ lethal dose}

Eight groups of four mice each were intravenously (i.v.) injected with $1,2.5,5,7.5,10,12.5,15$, or $20 \mu \mathrm{g}$ of 
M. surinamensis venom diluted in saline solution $(0.15 \mathrm{M} \mathrm{NaCl})$ for a final volume of $200 \mu \mathrm{l}$. The animals were observed for $48 \mathrm{~h}$ after inoculation of the venom, and their symptoms and mortality were documented. The lethal dose (LD50) was calculated using the Probit analysis method ${ }^{31}$ based on the number of mice that died within $48 \mathrm{~h}$ at each dose of venom.

\section{Venom neutralization by antielapidic serum}

The potency of the antielapidic serum was predetermined by calculating the $50 \%$ effective dose, defined as the dose at which $50 \%$ of the lethal effect exerted by a particular concentration of venom was neutralized with $1 \mathrm{ml}$ of the serum. Different dilutions of antielapidic serum produced at the Butantan Institute were mixed with $5 \times$ LD50 venom according to the recommendations of the World Health Organization ${ }^{32}$. Specifically, 1:1, 1:2, and 1:3 venom:serum dilutions were prepared and incubated for $30 \mathrm{~min}$ at $37^{\circ} \mathrm{C}$ in a water bath; the mixture (final volume of $200 \mu l)$ was i.v. injected into four groups of three mice each. M. surinamensis venom was administered at $5 \times$ LD50 as a control. The animals were observed for $48 \mathrm{~h}$, and the number of animals that died was noted. The potency of venom neutralization by the serum was determined by Probit analysis ${ }^{31}$.

\section{Evaluation of defibrinogenating and hemorrhagic activity}

The defibrinogenating activity of $M$. surinamensis venom was evaluated according to a previously described method $^{33}$, with some modifications. Three groups of four mice were i.v. injected with 10,15 , or $20 \mu \mathrm{g}$ of venom diluted in saline solution $(0.15 \mathrm{M}$ $\mathrm{NaCl}$ ) for a final volume of $200 \mu \mathrm{l}$ per sample. The animals were anesthetized with ether and exsanguinated via cardiac puncture $1 \mathrm{~h}$ after injection. Blood samples $(1 \mathrm{ml})$ in hemolysis tubes were allowed to stand at $26{ }^{\circ} \mathrm{C}$ for evaluation of blood coagulability. One animal per group was selected for assessment of hemorrhagic activity; the animals were anesthetized and sacrificed $2 \mathrm{~h}$ after venom injection, and their thoracic cavities were opened to determine if bleeding was present.

\section{Evaluation of PLA2 activity}

PLA2 activity was detected by $1 \%$ agarose gel electrophoresis using $3 \%$ egg yolk phosphatidylcholine in 0.04 PBS buffer $(\mathrm{pH}$ 8.1 ) as a substrate. The agarose solution and egg yolk were homogenized, and the mixture was applied to a plastic plate and allowed to gel at room temperature. Eight wells ( $4 \mathrm{~mm}$ in diameter) were created in the gel to form four columns. Column 1 served as a control for PLA2 activity and contained B. atrox venom (10 $\mu \mathrm{g}$ venom/20 $\mu$ l physiological saline solution); and columns $2-4$ contained M. surinamensis venom at concentrations of 10, 20, and $40 \mu \mathrm{g} / 20 \mu \mathrm{l}$ physiological saline, respectively. The samples were incubated at $37^{\circ} \mathrm{C}$ in a humid chamber for $24 \mathrm{~h}$. After incubation, the area forming a clear halo - reflecting PLA2 activity - was measured in millimeters using digital calipers.

\section{Immunoneutralization of PLA2 activity}

Inhibition of PLA2 activity was determined on plates containing $1 \%$ agarose gel using $3 \%$ egg yolk phosphatidylcholine in $0.04 \mathrm{M}$ PBS buffer ( $\mathrm{pH} 8.1$ ) as a substrate. Different amounts of antielapidic serum were used at $M$. surinamensis venom volume ratios of 1:1, 1:0.75, 1:0.50, 1:0.25, 1:0.10, and 1:0.05 ( $\mu \mathrm{g}$ of venom: $\mu \mathrm{l}$ of serum) to verify the efficacy of the serum in neutralizing PLA2 enzymatic activity. The venom/serum mixtures were incubated in a water bath at $37^{\circ} \mathrm{C}$ for $30 \mathrm{~min}$. Venom from M. surinamensis $(20 \mu \mathrm{g} / \mu \mathrm{l})$ and B. atrox $(10 \mu \mathrm{g} /$ $\mu 1)$ without antivenom served as controls. A $20-\mu$ l volume of the solution (venom + serum) was applied to each well of the gel, and the plates were incubated for $24 \mathrm{~h}$ at $37^{\circ} \mathrm{C}$ in a humid chamber. Gel areas were analyzed for the presence or absence of PLA2 activity. Specifically, the diameters of the halos (mm) were measured with a digital caliper. The inhibitory activity of the serum was quantified as the percent difference in PLA2 activity in the experimental group relative to the control group according to the following formula: $\%$ inhibition $=(100-$ PLA2 activity-related halo diameter) $\times 100 /$ (control PLA2 activityrelated halo diameter).

\section{Evaluation of proteolytic activity by zymography}

Proteolytic activity was assessed by zymography using a previously described method ${ }^{34}$. A $15 \%$ SDS-PAGE gel was prepared, and $1 \%(\mathrm{w} / \mathrm{v})$ casein, fibrinogen, and gelatin substrates were separately added to each gel before polymerization. After electrophoresis, gels were washed with Triton X-100 for $1 \mathrm{~h}$ at room temperature followed by ultrapure water for several minutes, then placed in glycine buffer ( $\mathrm{pH}$ 8.3) (gels with casein or fibrinogen) or collagenase buffer ( $\mathrm{pH} 7.5$ ) (gels with gelatin) in an oven at $37^{\circ} \mathrm{C}$ for $24 \mathrm{~h}$. B. atrox venom $(30 \mu \mathrm{g})$ was used as a control for proteolytic activity and as a molecular mass marker.

\section{In vitro evaluation of anticoagulant activity (recalcification time)}

The anticoagulant activity of the venom was evaluated as human plasma recalcification time ${ }^{35}$. Blood mixed with 3.8\% sodium citrate at a 1:9 ratio was centrifuged at $1610 \mathrm{~g}$ for 15 min, and the plasma was separated and refrigerated at $4{ }^{\circ} \mathrm{C}$. A $200-\mu 1$ volume of human plasma was added to hemolysis tubes and maintained in a water bath at $37^{\circ} \mathrm{C}$. Samples with 20,40 , or $80 \mu \mathrm{g}$ of M. surinamensis venom diluted in physiological saline were prepared and $20 \mu \mathrm{l}$ were separately transferred to the human plasma-containing tubes. At the predetermined concentration, each mixture was homogenized and then combined with $20 \mu 1$ of $0.4 \mathrm{M}$ calcium chloride $\left(\mathrm{CaCl}_{2}\right)$. Triplicate samples were evaluated by observing the recalcification (clot formation) start time. The control consisted of plasma alone combined with $20 \mu 1$ of $0.4 \mathrm{M} \mathrm{CaCl}_{2}$.

\section{Western blot analysis of competitive interaction}

Western blotting was performed as previously described ${ }^{36}$, with some modifications. Samples were subjected to 5\%-20\% SDS-PAGE and the proteins were transferred to a nitrocellulose membrane in transfer buffer with a constant current of $260 \mathrm{~mA}$ and $60 \mathrm{~V}$. The membrane was stained with Ponceau $\mathrm{S}$ to verify the efficiency of the transfer and then cut into strips that were washed thoroughly with distilled water to remove excess dye and treated with blocking solution composed of $5 \mathrm{~g}$ skim milk dissolved in $100 \mathrm{ml}$ Tris-buffered saline (TBS) with Tween 
20 (TBS-T) for $2 \mathrm{~h}$. The strips were washed three times for 5 min each with TBS-T solution. To quantify the number of antibodies capable of binding to venom toxins, samples were pre-incubated in a water bath at $37^{\circ} \mathrm{C}$ for $30 \mathrm{~min}$ in mixtures containing 5, 20, or $80 \mu \mathrm{g}$ of $M$. surinamensis venom with $4 \mu 1$ of antielapidic serum in $5 \mathrm{ml}$ TBS. Each preparation was applied to a nitrocellulose membrane strip and incubated for $1.5 \mathrm{~h}$. As a control, a strip treated with antielapidic serum only (diluted $1: 1,000$ in TBS) was incubated for $1.5 \mathrm{~h}$ at room temperature. Nitrocellulose membranes were washed three times with TBS-T for $5 \mathrm{~min}$ each and then incubated for $1.5 \mathrm{~h}$ at room temperature with the immunoenzyme conjugate [peroxidase-labeled antihorse immunoglobulin $\mathrm{G}(\mathrm{IgG})$ ] diluted 1:2,000 in TBS. After washing three times with TBS-T and twice with TBS for $5 \mathrm{~min}$ each, protein bands were detected by adding the peroxidase substrate $\left(1.5 \mathrm{mg}\right.$ of $4-\alpha$-chloro-1-naphthol in $24 \mu \mathrm{l}$ of $\mathrm{H}_{2} \mathrm{O}_{2}$, $0.5 \mathrm{ml}$ methanol, and $17.5 \mathrm{ml}$ TBS). Antigen-antibody binding ability was determined by competition assays.

\section{RESULTS}

\section{Molecular profiles of Micrurus surinamensis venom proteins}

Two-dimensional gel electrophoresis of venom samples in gels with a $\mathrm{pH}$ range of 3-10 revealed 43 spots, including 22 and 21 in the acidic and basic regions, respectively. A total of 26 spots had a mass below $23 \mathrm{kDa}$, and 17 had approximately the same mass above $50 \mathrm{kDa}$ but had different $\mathrm{pH}$ ranges (Figure 2A). Gels with a pH range of 4-7 had 42 spots, most of which were in the $\mathrm{pH}$ range of 5-6. Fourteen spots had a mass below $23 \mathrm{kDa}$, and $28 \mathrm{had}$ a mass above $50 \mathrm{kDa}$; the majority of spots in this acidic $\mathrm{pH}$ range had similarly high masses (Figure 2B). Spots detected in gels with a pH range of 7-11 had low masses below $23 \mathrm{kDa}$ (Figure 2C).

\section{Biological activities of toxins in Micrurus surinamensis venom}

Micrurus surinamensis venom at doses greater than $20 \mu \mathrm{g}$ was highly toxic, causing immediate muscle and respiratory paralysis and death in mice within a few minutes of administration. The following symptoms were observed following i.c. injection of $0.2,1,2$, and $4 \mu \mathrm{g}$ of venom: total muscle paralysis and difficulty breathing $(<1 \mathrm{~min})$; leaping, increased energy, hypersensitivity to touch and sound, compulsive scratching (30 $\mathrm{min}$ ); and convulsions followed by death at the higher doses. Symptoms caused by i.c. injection of $20 \mu 1$ of physiological saline solution (as a control for activity) were wheezing and apathy that ceased within 10 min of injection without leading to death. The following symptoms were observed following i.v. injection of $1,10,15$, or $20 \mu \mathrm{g}$ of $M$. surinamensis venom: difficulty breathing; muscle hypotonia; unilateral and bilateral ptosis (30 min); compulsive scratching (legs, genitalia, tail, head, nose, and eyes); muscle stretching in the hind legs (1:30h); and death due to respiratory arrest at the higher doses.

Probit analysis revealed that the LD50 of i.v. administered venom was $14 \mu \mathrm{g}(16.8-11.3)$ per $20 \mathrm{~g}$ body weight $(700 \mu \mathrm{g} / \mathrm{kg})$. The neutralizing capacity of the antielapidic serum was very
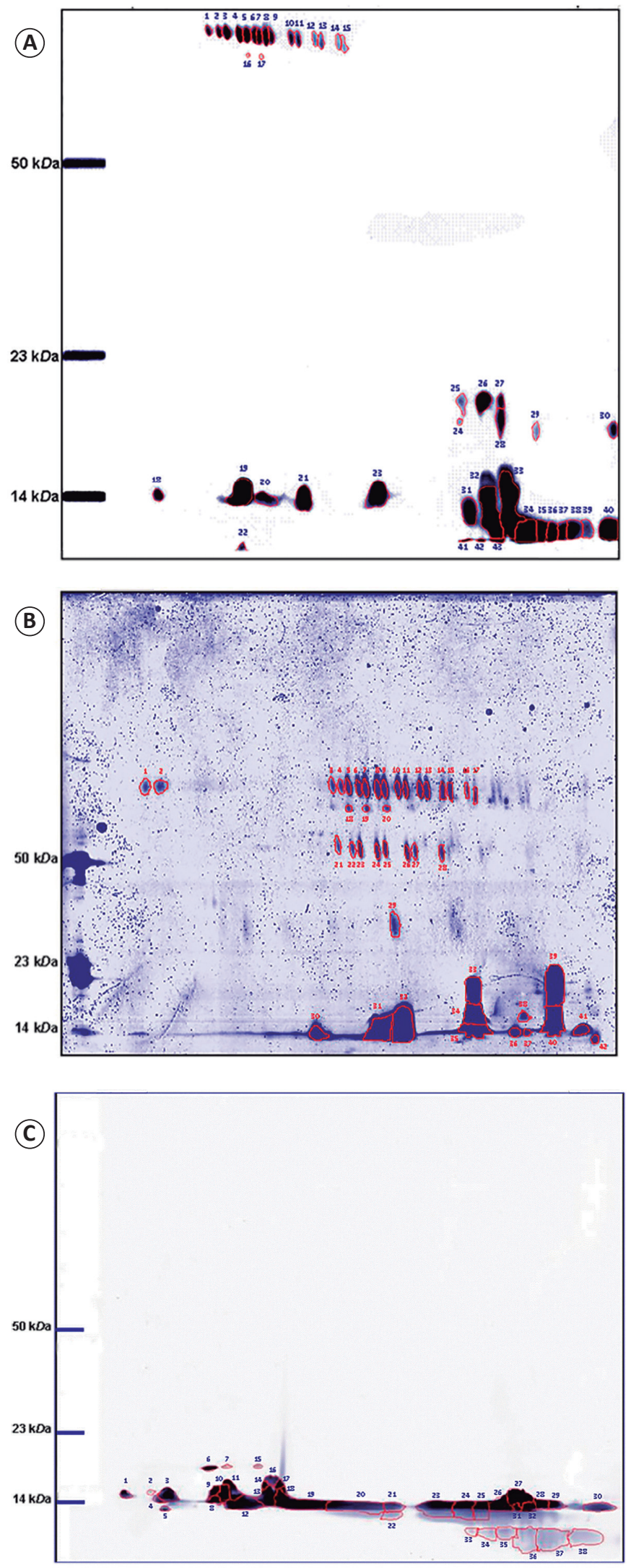

FIGURE 2 - Electrophoretic profile of Micrurus surinamensis venom. (A): 12.5\% SDS-PAGE with an IPG strip in the pI range of 3.0-10.0. (B): 5\%-20\% SDS-PAGE with an IPG strip in the pI range of 4-7. (C): 5\%-20\% SDS-PAGE with an IPG strip in the pI range of 7-11. Spots were analyzed using the ImageMaster 2D Platinum 6.0 system. Molecular mass markers were Bothrops atrox toxins. Gels were stained with Coomassie Blue R-250. SDS-PAGE: sodium dodecyl sulfate polyacrylamide gel electrophoresis; IPG: immobilized $\mathrm{pH}$ gradient; $\mathbf{p I}$ : isoelectric point. 
TABLE 1

Comparative biological activities of toxins in Micrurus surinamensis venom.

\begin{tabular}{lcc}
\hline Biological activities & In the present study & Tanaka et al., 2010 \\
\hline LD50 & $14 \mu \mathrm{g}$ intravenous & $58 \mu \mathrm{g}$ intraperitoneal \\
Anticoagulant activity & Present & Not tested \\
Hemorrhagic activity & Absent & Not tested \\
PLA2 activity & Present & Absent \\
Proteolytic activity & Absent & Absent \\
Hyaluronidase activity & Not tested & Present \\
\hline
\end{tabular}

LD50: 50\% lethal dose; PLA2: phospholipase A2 activity.

low, with a potency of $0.3(0.5-0.02) \mathrm{mg} / \mathrm{ml}$ (venom/serum). In animals i.v. injected with $7.5,10$, or $13 \mu \mathrm{g}$ of venom there was no hemorrhage in the thoracic cavity, nasal cavity, or genitalia. Blood collected from these animals coagulated within a normal time interval for mouse blood $(<60 \mathrm{~s})$. However, in vitro experiments revealed a delay in the coagulation time of venom-treated plasma as compared to that of control plasma. Specifically, human plasma clotted after 10 and $30 \mathrm{~min}$ in the presence of the lowest $(20 \mu \mathrm{g})$ and highest $(80 \mu \mathrm{g})$ doses of venom, respectively. Animals that received 15 or $20 \mu \mathrm{g}$ of venom were autopsied immediately after death and exhibited no hemorrhaging in the thoracic cavity or in other visible areas of the body, such as the external genitalia and nose (Table 1).

\section{Evaluation of serum-mediated neutralization of Micrurus surinamensis venom enzymatic activity}

Micrurus surinamensis venom exhibited low PLA2 activity compared to the control ( $10 \mu \mathrm{g}$ of $B$. atrox venom) at doses of 10,20 , and $40 \mu \mathrm{g}$ (Figure 3A). The antielapidic serum inhibited $100 \%$ of the PLA2 activity of $M$. surinamensis venom when administered at a ratio between 1:1 and 1:0.05 (Figure 3B). The antielapidic serum (maximum and minim doses of 20 and $1 \mu 1$, respectively) also inhibited $100 \%$ of the PLA2 activity of $M$. surinamensis venom. The venom had no caseinolytic, fibrinolytic, or gelatinolytic protease activity according to the zymography results (data not shown).

\section{Western blot analysis of competitive interaction}

A western blotting analysis revealed that the antielapidic serum had low potency (Figure 4). Antivenom $(4 \mu 1)+$ venom $(5,20$, and $80 \mu \mathrm{g})$ mixtures preincubated at $37^{\circ} \mathrm{C}$ for $30 \mathrm{~min}$ showed several low-intensity bands at $7-20 \mathrm{kDa}$ and especially around $14 \mathrm{kDa}$, although these exhibited variable signal intensity. The proteins were detected after just $1 \mathrm{~h}$ of reaction with peroxidase-specific substrates.

\section{DISCUSSION}

The venom of snakes in the genus Micrurus contains a complex mixture of proteins, approximately $90 \%$ of which are neurotoxins with low molecular masses of around $7-84 \mathrm{kDa}$ $(<12 \mathrm{kDa}, 43 \% \text {; } 14-32 \mathrm{kDa}, 47 \% \text {; and }>50 \mathrm{kDa}, 10 \%)^{37-40}$. The

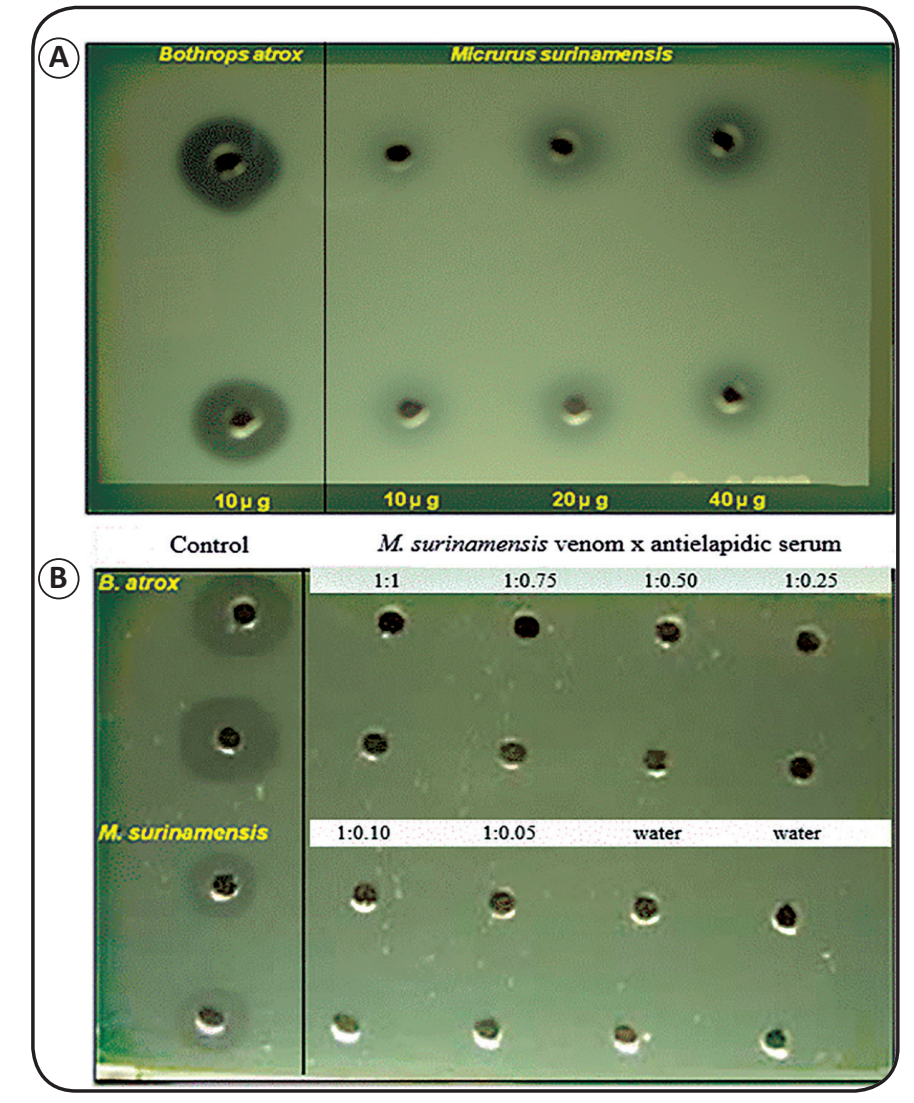

FIGURE 3 - (A): PLA2 activity of Micrurus surinamensis surinamensis venom proteins separated in agarose gels. Duplicate: 10,20 , and $40 \mu \mathrm{g} / 20 \mu \mathrm{l}$ venom. Control: 10 $\mu \mathrm{g}$ of Bothrops atrox venom. (B): Neutralization of the PLA2 activity of Micrurus surinamensis venom with antielapidic serum at different dilutions (venom/serum) prepared in duplicate. Controls: $10 \mu \mathrm{g}$ Bothrops atrox atrox venom and $20 \mu \mathrm{g}$ Micrurus surinamensis venom alone (duplicates). PLA2: phospholipase A2 activity.

venom of M. surinamensis differs from that of other Micrurus species owing to its abundance of peptides between $6-7 \mathrm{kDa}$, which was confirmed in the present work.

The 2D SDS-PAGE profiles of M. surinamensis venom revealed differences in venom composition. Previous studies 


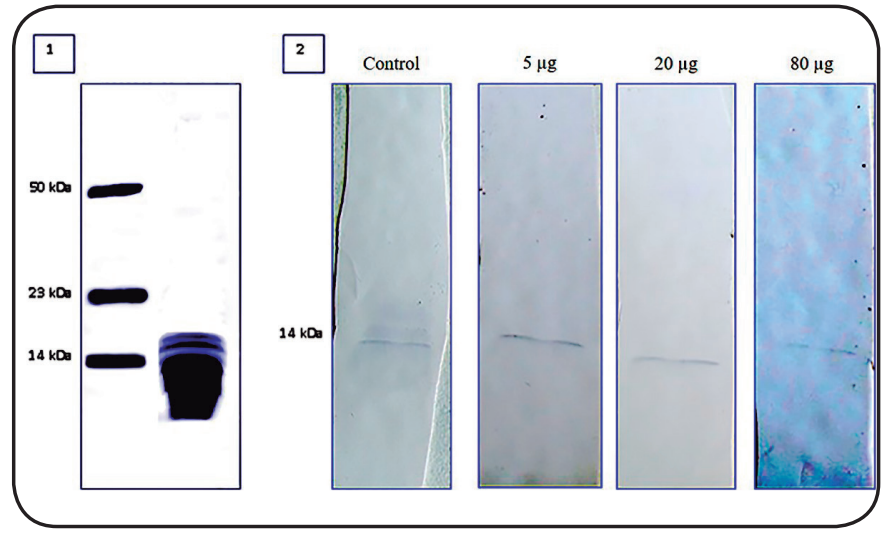

FIGURE 4 - Profile of Micrurus surinamensis venom proteins in a $20 \mu \mathrm{g}$ sample. (1) Sample subjected to 5\%-20\% gradient SDS-PAGE under non-reducing conditions. (2) Immune profiles of polyclonal antibodies against antielapidic serum. Control and antivenom $(4 \mu \mathrm{l}) \times$ venom $(5,20$, or $80 \mu \mathrm{g}$ ) were preincubated at $37^{\circ} \mathrm{C}$ for $30 \mathrm{~min}$. Molecular mass markers of Bothrops atrox venom toxins are shown to the left. Gels were stained with Coomassie Blue R-250. SDS-PAGE: sodium dodecyl sulfate polyacrylamide gel electrophoresis; IPG: immobilized $\mathrm{pH}$ gradient.

using this approach identified approximately 30 proteins within the $\mathrm{pH}$ range 3-10, with the most intense spots observed in the range of $11-25 \mathrm{kDa}$ and only one spot in the range of $30-150 \mathrm{kDa}$ that showed high similarity to L-aspartate oxidase ${ }^{41}$. In the present study, we identified 43 spots within the $\mathrm{pH}$ range of 3-10. All of the spots in the basic $\mathrm{pH}$ range had a low mass, whereas more than $60 \%$ of the spots in the acidic $\mathrm{pH}$ range had a high mass. A total of 17 spots had similar masses above 50kDa and an acidic $\mathrm{pH}$, suggesting that they were isoenzymes. In some species, isoenzymes with basic $\mathrm{pH}$ and masses of $8-13 \mathrm{kDa}$ have been isolated that exhibit various biological activities (e.g., cardiotoxic, neurotoxic, PLA2, and hemorrhage-inducing) and, in some cases, lethality in association with hemoptysis and hemoglobinuria ${ }^{42-44}$.

Despite their similar profiles, each type of snake venom has peculiarities in terms of protein composition and abundance ${ }^{45,46}$. Additionally, differences in snake venom proteomes within the same species inhabiting different areas are not uncommon ${ }^{47}$. Proteomic variations in the venom of Micrurus species may be associated with differences in their geographic location and/or habitat as well as seasonal variations, dietary factors, age, sexual dimorphism, and even evolutionary history.

In this study, toxins from M. surinamensis did not cause bleeding and produced symptoms typical of venom from this genus, including uni- and/or bilateral ptosis, muscular hypotonia, spasms, respiratory failure, and exophthalmos. M. surinamensis venom exhibited high neurotoxicity, causing death via respiratory paralysis within minutes of injection. Toxins present in Micrurus venoms generally do not cause localized or systemic bleeding and induce mild myonecrosis ${ }^{48,11}$, while M. surinamensis venom is not known to induce myotoxicity, hemorrhage, or edema ${ }^{49}$. At high concentrations, $M$. altirostris venom does not cause bleeding, dermonecrosis, or coagulant activity ${ }^{37}$; venoms of M. averyi and M. fulvius cause hemorrhaging, renal damage, and severe inflammation ${ }^{49,50}$. In some cases, PLA2 is responsible for inducing severe bleeding and myoglobinuria ${ }^{51}$, but owing to the lethality of the neurotoxins present in the venom, these symptoms are often not manifested.

In general, snake toxins are associated with less bleeding and more neurotoxic effects; however, the venoms of snakes in the Viperidae and Crotalidae families cause serious bodily injury due to bleeding within vital organs and blood circulation impairment caused by clot formation, edema, and necrosis. These symptoms are mainly attributed to serine and metalloproteases responsible for proteolytic degradation in mammalian blood plasma and tissues, which may function as blood coagulation activators or inhibitors ${ }^{15,52-54}$.

The venoms of some species of the genera Naja, Bungarus, and Micrurus lack proteolytic activity against gelatin, casein, and fibrinogen ${ }^{55,56}$; this was also true of the venom of the species examined in the present study. However, high concentrations of M. surinamensis venom caused an increase in human plasma coagulation time, suggesting that it has anticoagulant activity. Proteases are known to inhibit platelet aggregation ${ }^{57}$ and PLA2 inactivates blood clotting factors to block the coagulation cascade $^{58}$. Thus, PLA2 concentration may also be related to anticoagulant activity ${ }^{44,59}$.

Venom toxins of most coral snakes exhibit PLA2 activity along with neurotoxic and myotoxic effects ${ }^{60}$. Both $\alpha$ - and $\beta$-type neurotoxins are responsible for the lethality of the venom in mice and are 10 times more potent when directly injected into the CNS. Thus, although these neurotoxins have no effects in the peripheral nervous system (PNS), even small amounts are highly toxic in the $\mathrm{CNS}^{61}$, causing damage in the cerebral cortex, rostrocaudal region of the brain, hemispheric white matter, corpus callosum, fornix, and hippocampus ${ }^{14}$. Similar damage is caused by some three-finger neurotoxins that bind to rat hippocampus-specific muscarinic acetylcholine and A-type $\gamma$-aminobutyric acid receptors following jaw paralysis and intense seizures induced by intracerebroventricular injection of venom ${ }^{61,62}$.

Four fractions $(7-22 \mathrm{kDa})$ exhibiting neurotoxic PLA2 activity isolated from $M$. lemniscatus venom caused severe symptoms of envenomation in the mouse $\mathrm{CNS}^{63}$. Small doses $(1-2.1 \mu \mathrm{g} / \mu \mathrm{l})$ induced a variety of detectable symptoms, including spasms, breathing difficulty, limbic seizures, cortical and hippocampal epileptic discharges, episodes of convulsion, and ultimately death (in $80 \%$ of animals); high doses $(4.5 \mu \mathrm{g} / \mu \mathrm{l})$ caused symptoms consistent with severe intoxication such as reduced motor activity, hypersensitivity to touch and sound, aggression, and death. Histological analysis revealed massive hippocampal neuronal loss. These results demonstrate that $M$. surinamensis venom is highly neurotoxic to both the PNS and CNS. Clarifying the molecular mechanisms underlying these effects can lead to the development of new drugs for the treatment of neurological diseases based on neuropeptides produced by these snakes ${ }^{64}$.

The species examined in the present work showed low PLA2 activity that was effectively neutralized by antielapidic serum from the Butantan Institute. A previous study found 
no phospholipase activity in $M$. surinamensis venom, and antivenom produced by the Butantan Institute was minimally effective in detecting venom components ${ }^{65}$. In the present study, M. surinamensis venom components larger than $10 \mathrm{kDa}$ were only weakly detected by western blotting. Our in vitro tests revealed the presence of antibodies in the antielapidic serum that recognized and neutralized proteins of approximately $14 \mathrm{kDa}$ in M. surinamensis venom, but not bands corresponding to neurotoxins smaller than $10 \mathrm{kDa}$. These results demonstrate that individual snakes of the same species have unique venom protein components and immunological profiles.

Our in vivo analysis showed that the antielapidic serum had low efficacy in neutralizing $M$. surinamensis venom components that exhibited high neurotoxicity by i.v. injection $(14 \mu \mathrm{g} / 20 \mathrm{~g}$ venom/mouse), indicating that high doses of serum are required for complete neutralization ${ }^{66,67}$. The low recognition of these neurotoxins is a significant limitation given their abundance and toxicity ${ }^{68}$.

The immune profile of $M$. surinamensis was distinct from that of other species. In particular, the toxic components of its venom showed limited reactivity with the antielapidic serum ${ }^{65,69}$ produced in Brazil by hyperimmunizing horses with Micrurus corallinus and Micrurus frontalis venoms obtained from the Butantan Institute. Despite their small size and corresponding low venom inoculation capacity, high doses of serum are recommended for envenomations involving coral snakes ${ }^{7}$. The intra-species variability of coral snake venom raises concerns regarding the effectiveness of sera developed using venoms produced by a limited number of coral snake species ${ }^{70}$. A monoclonal antibody against $M$. nigrocintus nigrocintus reacted with $M$. surinamensis venom, indicating that the former belongs to a group with a different antigenic profile than other Micrurus species of medical importance in Brazil ${ }^{39}$. Geographic and dietary variations as well as phylogenetic factors and mutations account for the diversity in snake venom composition. Although diet is the main contributing factor ${ }^{71}$, other evolutionary forces driven by natural selection such as allelic mutations in an enzyme that leads to structural changes in the protein may be equally important ${ }^{72}$.

A recent study evaluated the immunogenic potential of venoms of different Micrurus species to ensure good crossreactivity with antielapidic sera produced in experimental animals and to establish an antigenic mixture for generating polyvalent antivenoms with higher efficacy than those used to treat envenomation in humans ${ }^{69}$. The results were positive for most but not all of the species investigated; in fact, the M. surinamensis venom was less efficiently recognized by the antivenom, underscoring the difficulty of this task. Additional basic and clinical studies are needed to generate a monovalent serum or venom that includes these species in the pool used to produce commercial antivenom. Snake bites remain a serious public health problem that have generally been neglected by the authorities and the general population ${ }^{73}$. Thus, there are many outstanding challenges and issues that must be addressed to promote snake bite prevention and to develop effective treatments for envenomation.

\section{Acknowledgments}

The authors thank Prof. Paulo Friederich Bührnheim (in memoriam); the Snakebite Center at the Tropical Medicine Foundation Doctor Heitor Vieira Dourado; Amazon State University; and the Federal University of Amazon.

\section{Conflict of interest}

The authors declare that have no conflicts of interest.

\section{Financial support}

This study was supported by Amazonas State Research Foundation [Fundação de Amparo à Pesquisa do Estado do Amazonas (FAPEAM)], Financier of Studies and Projects [Financiadora de Estudos e Projetos (FINEP)], National Council for Scientific and Technological Development [Conselho Nacional de Desenvolvimento Cientifico e Tecnológico $(\mathrm{CNPq})]$, and the Proteome Network of Amazon.

\section{REFERENCES}

1. Costa HC, Bérnils RS. Répteis brasileiros: lista de espécies 2015. São Paulo: Sociedade Brasileira de Herpetologia; 2015; 4(3):75-93. [Internet]. [updated 2015 August 10; cited 2017 March 24]. Available from: http://www.sbherpetologia.org.br.

2. Orr RT. Biologia dos Vertebrados. 5th ed. São Paulo: Roca; 1986. $508 \mathrm{p}$.

3. Roze JA. New world coral snakes (Elapidae): a taxonomic and biological summary. Mem Inst Butantan. 1982;46(1):305-38.

4. Hoge AR, Romano-Hoge SARWL. Sinopse das serpentes peçonhentas do Brasil. Mem Inst Butantan. 1978/79;42/43: 373-496.

5. Santos MC, Martins M, Boechat AL, de Sá Neto RP, Oliveira ME. Serpentes de Interesse Médico da Amazônia: Biologia, Venenos e Tratamento de Acidentes. Manaus: Universidade do Amazonas; 1995. 70p.

6. Bucaretchi F, Capitani EM, Vieira RJ, Rodrigues CK, Zannin M, Da Silva Jr NJ, et al. Coral snake bites (Micrurus spp.) in Brazil: a review of literature reports. Clin Toxicol (Phila). 2016;54(3):222-346

7. Bucaretchi F, Hyslop S, Vieira RJ, Toledo AS, Madureira PR, Capitani EM. Bites coral snakes (Micrurus spp.) in Campinas, state of São Paulo, southeastern Brazil. Rev Inst Med Trop Sao Paulo. 2006;48(3):141-5.

8. Ministério da Saúde. Manual de diagnóstico e tratamento de acidentes ofídicos. Brasília: Fundação Nacional de Saúde; 2001. $120 \mathrm{p}$.

9. Urdaneta AH, Bolaños F, Gutierrez JM. Feeding behavior and venom toxicity of coral snake Micrurus nigrocinctus (Serpentes: Elapidae) on its natural prey in captivity. Comp Biochem Physiol C Toxicol Pharmacol. 2004;138(4):485-92.

10. Serafim FG, Reali M, Cruz-Hofling MA, Fontana MD. Action of Micrurus dumerilii carinicauda coral snake venom on the mammalian neuromuscular junction. Toxicon. 2002;40(2):167-74.

11. Gutiérrez JM, Chaves F, Rojas E, Bolaños R. Efectos locales inducidos por el veneno de la serpiente coral Micrurus nigrocinctus em ratón blanco. Toxicon. 1980;18(5-6):633-9.

12. Arni RK, Ward RJ. Phospholipase $\mathrm{A}_{2}-$ a structural review. Toxicon. 1996;34(8):827-41.

13. Carredano E, Westerlund B, Persson B, Saarinen M, Ramaswamy $\mathrm{S}$, Eaker D, et al. The three-dimensional structures of two toxins from snake venom throw light on the anticoagulant and neurotoxic sites of phospholipase $A_{2}$. Toxicon. 1998;36(1):75-92. 
14. Clapp LE, Klette KL, Decoster MA, Bernton E, Petras JM, Dave $\mathrm{JR}$, et al. Phospholipase $\mathrm{A}_{2}$-induced neurotoxicity in vitro and in vivo in rats. Brain Res. 1995;693(1-2):101-11.

15. Kini RM. Structure-function relationships and mechanism of anticoagulant phospholipase $\mathrm{A}_{2}$ enzymes from snake venoms. Toxicon. 2005;45(8):1147-61.

16. Wickramaratna JC, Fry BG, Aguilar MI, Kini RM, Hodgson WC. Isolation and pharmacological characterization of a phospholipase $\mathrm{A}_{2}$ myotoxin from the venom of the Irian Jayan death adder (Acanthophis rugosus). Br J Pharmacol. 2003;138(2):333-42.

17. Cruz-Höfling MA, Rodrigues-Simioni L, Vital-Brazil O. Ultrastructure changes in neuromuscular junctions of mouse diaphragm caused by the venom of the coral snake Micrurus corallinus. Mem Inst Butantan. 1983/84;47/48:95-105.

18. Huang LF, Zheng JB, Xu Y, Song HT, Yu CX. A snake venom phospholipase $\mathrm{A}_{2}$ with high affinity for muscarinic acetylcholine receptors acts on guinea pig ileum. Toxicon. 2008;51(6):1008-16.

19. Jolkkonen M, Giersbergen PLMV, Hellman U, Wernstedt C, Oras A, Satyapan N, et al. Muscarinic toxins from the black mamba Dendroaspis polylepis. Eur J Biochem. 1995;234(2):579-85.

20. Karlsson E, Jolkkonen M, Mulugeta E, Onali P, Adem A. Snake toxins with high selectivity for subtypes of muscarinic acetylcholine receptors. Biochimie. 2000;82(9-10):793-806

21. Vital-Brazil O. Coral snake venoms: mode of action and pathophysiology of experimental envenomation. Rev Inst Med Trop Sao Paulo. 1987;29(3):119-26.

22. Kumar TKS, Pandian SK, Srisailam S, Yu C. Structure and function of snake venom cardiotoxins. J Toxicol Toxin Rev. 1998;17(2):183-211.

23. Nirthanan S, Gopalakrishnakone P, Gwee MCE, Khoo HE, Kini RM. Non-conventional toxins from elapid venoms. Toxicon. 2003;41(4):397-407.

24. Noronha MDN, Souza ARB, Bührnheim PF. Estudo epidemiológico dos acidentes ofídicos atendidos na FMT/IMT-AM, de janeiro de 1995 a outubro de 1999. Rev Soc Bras Med Trop. 2000;33(Suppl. I):162-3.

25. Buhrnheim PF, Lima HCL, Oliveira MEES. Ocorrência de serpentes peçonhentas na Amazônia e acidentes ofídicos no Amazonas. Rev Soc Bras Med Trop. 1988;21(Suppl. I):119.

26. Cunha OR, Nascimento FP. Ofídios da Amazônia X: as cobras da região leste do Pará. Publicações Avulsas. Museu Paraense Emílio Goeldi. 1978;31:1-218. Disponível em: http://repositorio.museugoeldi.br/handle/mgoeldi/904.

27. Morais DH, Ávila RW, Kawashita-Ribeiro RA, Carvalho MA. Squamata, Elapidae, Micrurus surinamensis (Cuvier, 1817): new records and distribution map in the state of Mato Grosso, Brazil, with notes on diet and activity period. Check List. 2011;7(3):350-1.

28. Da Silva Jr NJ, Aird SD. Prey specificity, comparative lethality and compositional differences of coral snake venoms. Comp Biochem Physiol C Toxicol Pharmacol. 2001;128(3):425-56.

29. Aird SD, Da Silva Jr NJ. Comparative enzymatic composition of Brazilian coral snake (Micrurus) venoms. Comp Biochem Physiol B. 1991;99(2):287-94.

30. Schägger H, Von Jagow G. Tricine-sodium dodecyl sulfatepolyacrylamide gel electrophoresis for the separation of proteins in the range from 1 to $100 \mathrm{kDa}$. Anal Biochem. 1987;166(2):368-79.

31. Finney DJ. Probit analysis. 3rd ed. New York: Cambridge University Press; 1971. 333p.

32. World Health Organization. Progress in the characterization of venoms and standardization of antivenoms. WHO Offset Publ. 1981;(58):1-44. PMID: 7245916.
33. Theakston RDG, Reid HA. Development of simple standart assay procedures for the characterization of snake venoms. Bull World Health Organ. 1983;61(6):949-56.

34. Heussen C, Dowdle EB. Eletrophoretic analisys of plasminogen activators in poliacrilamide gels containg sodium dodecyl sulfate and copolymerized substrates. Anal Biochem. 1980;102(1):196-202.

35. Stocker KF, Meier J. Thrombin-like snake venom enzymes. In: Pirkle H, Markland FS, editors. Hemostasis and animal venoms. New York: Marcel Dekker; 1988. p. 67-84.

36. Towbin H, Staehelin T, Gordon J. Electrophoretic transfer of proteins from polyacrylamide gels to nitrocellulose sheets: procedure and some applications. Proc Natl Acad Sci USA. 1979;76(9):4350-4.

37. Moraes FV, Sousa-E-Silva MCC, Barbaro KC, Leitão MA, Furtado MFD. Biological and immunochemical characterization of Micrurus altirostris venom and serum neutralization of its toxic activities. Toxicon. 2003;41(1):71-9.

38. Alape-Girón A, Gustafsson B, Lomonte B, Thelestam M, Gutiérrez JM. Immunochemical characterization of Micrurus nigrocinctus nigrocinctus venom with monoclonal and polyclonal antibodies. Toxicon. 1994;32(6):695-712

39. Alape-Girón A, Lomonte B, Gustafsson B, Da Silva Jr NJ, Thelestam M. Electrophoretic and immunochemical studies of Micrurus snake venoms. Toxicon. 1994;32(6):713-23.

40. Da Silva Jr NJ, Griffin PR, Aird SD. Comparative chromatography of Brazilian coral snake (Micrurus) venoms. Comp Biochem Physiol. 1991;100B(1):117-26.

41. Olamendi-Portugal T, Batista CVF, Restano-Cassulini R, Pando V, Villa-Hernandez O, Vargas AZM, et al. Proteomic analysis of the venom from the fish eating coral snake Micrurus surinamensis: novel toxins, their function and phylogeny. Proteomics. 2008;8(9):1919-32.

42. Vergara I, Pedraza-Escalona M, Paniagua D, Restano-Cassulini R, Zamudio F, Batista CVF, et al. Eastern coral snake Micrurus fulvius venom toxicity in mice is mainly determined by neurotoxic phospholipases $A_{2}$. J Proteomics. 2014;105:295-306.

43. Chang LS, Huang HB, Lin SR. The multiplicity of cardiotoxins from Naja naja atra (Taiwan Cobra) venom. Toxicon. 2000;38(8):1065-76.

44. Francis BR, Da Silva Jr NJ, Seebart C, Silva LLC, Schimidt JJ, Kaiser II. Toxins isolated from the venom of the Brazilian coral snake (Micrurus frontalis frontalis) include hemorrhagic type phospholipases $\mathrm{A}_{2}$ and postsynaptic neurotoxins. Toxicon. 1997;35(8):1193-203.

45. Takasaki C, Suzuki J, Tamiya N. Purification and properties of several phospholipases $\mathrm{A}_{2}$ from the venom of Australian king brown snake (Pseudechis australis). Toxicon. 1990;28(3):319-27.

46. Kulkeaw K, Chaicumpa W, Sakolvaree Y, Tongtawe P, Tapchaisri P. Proteome and immunome of the venom of the thai cobra, Naja kaouthia. Toxicon. 2007;49(7):1026-41.

47. Tan NH, Ponnudurai G. The biological properties of venoms of some American coral snakes (genus Micrurus). Comp Biochem Physiol. 1992;101B (3):471-4.

48. Remuzgo C, Alvarez MP, Rodriguez E, Lazo F, Yarleque A. Micrurus spixii (peruvian coral sanke) venom - preliminary biochemical and enzymatic characterization. J Venom Anim Toxins Incl Trop Dis. 2002;8(1):1-6.

49. Barros ACS, Fernandes DP, Ferreira LCL, Santos MC. Local effects induced by venoms from five species of genus Micrurus sp. (coral snakes). Toxicon. 1994;32(4):445-52.

50. Gutiérrez JM, Lomonte B, Portilla E, Cerdas L, Rojas E. Local effects induced by coral snake venoms: evidence of myonecrosis after experimental inoculations of venoms from five species. Toxicon. 1983;21(6):777-83. 
51. Roodt AR, Lago NR, Stock RP. Myotoxicity and nephrotoxicity by Micrurus venoms in experimental envenomation. Toxicon. 2012;59(2):356-64.

52. Jin Y, Lee WH, Zhang Y. Molecular cloning of serine proteases from elapid snake venoms. Toxicon. 2007;49(8):1200-7.

53. Kini RM, Evans HJ. Inhibition of platelet aggregation by a fibrinogenase from Naja nigricollis venom is independent of fibrinogen degradation. Biochim Biophys Acta. 1991;1095(2):117-21.

54. Teixeira CFP, Fernandes CM, Zuliani JP, Zamuner SF. Inflammatory effects of snake venom metalloproteinases. Mem Inst Oswaldo Cruz. 2005;100(1):181-4.

55. Zhang Y, Xiong YL, Bom C. An activator of blood coagulation factor $\mathrm{X}$ from the venom of Bungarus fasciatus. Toxicon. 1995;33(10):1277-88.

56. Tambourgi DV, dos Santos MC, Furtado MFD, de Freitas MCW, da Silva WD, Kipnis TL. Pro-inflammatory activities in elapid snake venoms. Br J Pharmacol. 1994;112(3):723-7.

57. Kerns RT, Kini RM, Stefansson S, Evans HJ. Targeting of venom phospholipases: the strongly anticoagulant phospholipase $\mathrm{A}_{2}$ from Naja nigricollis venom binds to coagulation factor Xa to inhibit the prothrombinase complex. Arch Biochem Biophys. 1999;369(1):107-13.

58. Cecchini AL, Marcussi S, Silveira LB, Borja-Oliveira CR, Rodrigues-Simioni L, Amara S, et al. Biological and enzymatic activities of Micrurus sp. (coral) snake venoms. Comp Biochem Physiol A Mol Integr Physiol. 2005;140(1):125-34.

59. Terra ALC, Moreira-Dill LS, Simões-Silva R, Monteiro JRN, Cavalcante WLG, Gallacci M, et al. Biological characterization of the Amazon coral Micrurus spixii snake venom: isolation of a new neurotoxic phospholipase $A_{2}$. Toxicon. 2015;103:1-11.

60. Rosso JP, Vargas-Rosso O, Gutiérrez JM, Rochat H, Bougis PE. Characterization of $\alpha$-neurotoxin and phospholipase $A_{2}$ activities from Micrurus venoms: determination of the amino acid sequence and receptor-binding ability of the major $\alpha$-neurotoxin from Micrurus nigrocinctus nigrocinctus. Eur J Biochem. 1996;238(1):231-9.

61. Silva DC, Medeiros WAA, Batista IFC, Pimenta DC, Lebrun I, Abdalla FMF, et al. Characterization of a new muscarinic toxin from the venom of the Brazilian coral snake Micrurus lemniscatus in rat hippocampus. Life Sci. 2011;89(25-26):931-8.

62. Rosso JP, Schwarz JR, Diaz-Bustamante M, Céard B, Gutiérrez JM, Kneussel M, et al. MmTX1 and MmTX2 from coral snake venom potently modulate GABA receptor activity. Proc Natl Acad Sci USA. 2015;112(8):E891- E900.

63. Oliveira DA, Harasawa C, Seibert CS, Casais e Silva LL, Pimenta DC, Lebrun I, et al. Phospholipases $\mathrm{A}_{2}$ isolated from Micrurus lemniscatus coral snake venom: bahavioral, electroencephalographic and neuropathological aspects. Brain Res Bull. 2008;75(5):629-39.

64. Goswami PK, Samant M, Srivastava RS. Snake venom, antisnake venom \& potential of snake venom. Int J Pharm Pharm Sci. 2014;6(5):4-7.

65. Tanaka GD, Furtado MFD, Portaro FCV, Sant'Anna OA, Tambourgi DV. Diversity of Micrurus snake species related to their venom toxic effects and the prospective of antivenom neutralization. PLoS Negl Trop Dis. 2010;4(3):e622.

66. Fry BG, Wickramaratna JC, Jones A, Alewood PF, Hodgson WC. Species and regional variations in the effectiveness of antivenom against the in vitro neurotoxicity of Death adder (Acanthophis) venoms. Toxicol Appl Pharmacol. 2001;175(2):140-8.

67. Silva ARBP, Yamagushi IK, Morais JF, Higashi HG, Raw I, Ho PL, et al. Cross reactivity of different specific Micrurus antivenom sera with homologous and heterologous snake venoms. Toxicon. 2001;39(7):949-53.

68. Ciscotto PHC, Rates B, Silva DAF, Richardson M, Silva LP, Andrade $\mathrm{H}$, et al. Venomic analysis and evaluation of antivenom cross-reactivity of South American Micrurus species. J Proteomics. 2011;74(9):1810-25.

69. Tanaka GD, Sant'Anna OA, Marcelino JR, Lustoza da Luz AC, Teixeira da Rocha MM, Tambourgi DV. Micrurus snake species: venom immunogenicity, antiserum cross-reactivity and neutralization potential. Toxicon. 2016;117:59-68.

70. Carvalho AV, David CF, Pessoa AM, da Silva Jr NJ. Um estudo do rendimento do veneno de cobras corais brasileiras e seu uso na avaliação do soro antielapídico. Sci Med. 2014;24(2):142-9.

71. Daltry JC, Wüster W, Thorpe RS. Diet and snake venom evolution. Nature. 1996;379(6565):537-40.

72. Sasa M. Diet and snake venom evolution: can local selection alone explain intraspecific venom variation. Toxicon. 1999;37(2):249-52.

73. Gutiérrez JM. Current challenges for confronting the public health problem of snakebite envenoming in Central America. J Venom Anim Toxins Incl Trop Dis. 2014;20(1):7. PMCID: PMC3973843. 